\title{
The Extent, Nature and Distribution of Child Poverty in India
}

\author{
Professor David Gordon \\ Dr Shailen Nandy \\ Townsend Centre for International Poverty Research \\ University of Bristol \\ 8 Priory Road, \\ Bristol, BS8 1TZ, UK, \\ Email: dave.gordon@bristol.ac.uk \\ March 2016 \\ Submitted to Indian Journal of Human Development
}

\section{Brief biographies}

David Gordon is Professorial Research Fellow at the University of Bristol. He is Director of the Townsend Centre for International Poverty Research.

Shailen Nandy is a non-progressable Research Fellow in the School for Policy Studies at the University of Bristol. 


\begin{abstract}
Despite a long history, research on poverty has only relatively recently examined the issue of child poverty as a distinct topic of concern. This paper examines how child poverty and wellbeing are now conceptualized, defined and measured, and presents a portrait of child poverty in India by social and cultural groups, and by geographic area. In December 2006, the UN General Assembly adopted a definition of child poverty which noted that children living in poverty were deprived of (among other things) nutrition, water and sanitation facilities, access to basic health-care services, shelter and education. The definition noted that while poverty hurts every human being "it is most threatening and harmful to children, leaving them unable to enjoy their rights, to reach their full potential and to participate as full members of the society”.

Researchers have developed age specific and gender sensitive indicators of deprivation which conform to the UN definition of child poverty and which can be used to examine the extent and nature of child poverty in low and middle income countries. These new methods have 'transformed the way UNICEF and many of its partners both understood and measured the poverty suffered by children' (UNICEF 2009). This paper uses these methods and presents results of child poverty in India based on nationally representative household survey data for India.
\end{abstract}

\title{
Keywords: India, Child Poverty, Deprivation, Malnutrition, Social Groups
}

\section{Acknowledgments}

We acknowledge the financial support of UNICEF and DFID for funding the development of the child poverty measurement methodology. The Canadian Institutes of Health Research (CIHR/IRS) funded 'Examining the impact of social policies on health equity' project provided financial support for the work on this paper (Grant ROH 115209), as did the Swedish Research Council (Grant: 2011-1643) and UK ESRC (Grant: ES/K001809/1). 


\section{Introduction}

More children live in India than in any other country; around 27 million children are born in India each year which represents about one in every five live births in the World (UNICEF, 2011; Central Statistics Office, 2012). No global estimates of child poverty are meaningful without high quality data for the children of India, and it will prove impossible to eradicate poverty during the $21^{\text {st }}$ Century without a solution to the problem of child poverty in India.

There is no need for any child, anywhere, in the $21^{\text {st }}$ Century, to starve, to go without clean drinking water, toilets, access to basic health care, and education. Providing children with all these things will not have any significant impact on the lifestyles of the 'rich' is neither an 'Act of God' nor and 'Act of Nature' nor is it inevitable: it is a political choice (Gordon 2015).

Successive governments in India have acknowledged the need to do more to help the 'poor' and that child poverty is not a party political issue. Politicians in India agree child poverty is a 'bad' thing which should be reduced and eventually eradicated. There is also unanimity about how to eradicate child poverty. The economics are very simple and are entirely concerned with redistribution - where sufficient resources ${ }^{\mathrm{ii}}$ are redistributed from adults to children in India, there is no child poverty; where insufficient resources are redistributed from adults to children child poverty is inevitable (Gordon, 2004). Children cannot and should not do paid work to generate the resources they need to escape from poverty. This is the job of adults - Article 24 of India's Constitution prohibits child labour below the age of fourteen. Children should be spending their time playing and learning, not working at paid labour. 
India has witnessed significant progress in development and poverty reduction over the past twenty-five years. Table 1 illustrates the progress that India has made in meeting some of its Millennium Development Goal (MDG) obligations. Targets shaded grey have already been met or are likely to have been met by 2015; major MDG goals not shaded were unlikely to have been met by 2015 . It should be noted that according to the UN, India has already met its MDG target to halve the proportion of people living in extreme poverty, based on the national poverty line (Tendulkar Methodology), although progress has been slower when estimates are based on the World Bank's \$1.25 per day at Purchasing Power Parity (PPP) methodology.

\section{$<<<$ TABLE 1 HERE $\gg>>$}

\section{Poverty Measurement in India}

Valid and reliable measures of poverty are required in order to effectively and efficiently target anti-poverty policies towards those with the greatest needs. For most of the past fifty years poverty has been measured in India based on the cost of buying sufficient food to meet a calorific norm, which ranged between 1,800 and 2,400 K-cal per capita (Joshi, 1997). In 2005, the government established a new Expert Group to review the methodology for the estimation of poverty, which was chaired by Suresh Tendulkar. They recommended abandoning the calorie intake norm budget standards methodology and the adoption of a more comprehensive budget standard in both urban and rural India - a uniform poverty line basket (PLB). The new budget standard included the costs of: cereal, pulses, milk, edible oil, non-vegetarian items, vegetables, fresh fruits, dry fruits, sugar, salt \& spices, other food, intoxicants, fuel, clothing, footwear, education and medical costs, entertainment, personal \& toilet goods and some other goods, services and durables (Government of India, 2009). 
The Tendulkar methodology was widely criticised as setting the poverty line at a level which was too low and which 'did not reflect the changing times and aspirations of the people of India' (Government of India, 2014, p1). So another Expert Group was set up in 2012, which was chaired by C Rangarajan to once again review the poverty line methodology. In 2014, they reported and recommended increasing the poverty line from Rs 27 to Rs 32 per day in rural areas and from Rs 33 to Rs 47 in towns and cities; this resulted in a 35\% increase in the size of the poor population (from 270 to 363 million). This new poverty line methodology returned to a calorie intake norm of 2,155 kcal per person per day in rural areas and 2,090 kcal per person per day in urban areas. However, in deriving the food basket it also includes fat and protein food intake norms so it is nutritionally more sophisticated than previous food budget standards in India (Government of India, 2014). Ray and Sinha (2014) noted and have argued that the Rangarajan Expert Committee on poverty measurement 'missed the opportunity to go beyond the expenditure-based poverty rates and examine the possibility of a wider multidimensional view of deprivation'.

While the Tendulkar (Government of India, 2009) and Rangarajan (Government of India, 2014) methodologies do include the costs of educating children, they do not explicitly include age and gender sensitive estimates of the income or expenditure needed for children to avoid poverty. In practice, the Tendulkar and Rangarajan poverty measurement methodologies treat children as a property of their households and do not produce separate estimates of the extent and nature of child poverty.

Calorific food basket poverty measurement methodologies have often been the subject of great controversy in India. For example, political disagreement about the effects of economic reforms on poverty since 1991 and changes to the food diary recall period methodology in the 
$55^{\text {th }}$ round (1999-2000) of the National Sample Survey (NSS) resulted in considerable academic and public controversy, which has been called the "Great Indian Poverty Debate" by Deaton and Kozel (2005a; 2005b). There remains little consensus in India about either the poverty prevalence rate or about poverty trends during the 1990s (Panagariya and Mukim 2013; Himanshu and Sen 2014).

A wider multi-dimensional view of deprivation is used in India by the Ministry of Rural Development which conducts the Below Poverty Line (BPL) Census with the objective of identifying the BPL households in the rural areas who could be eligible to benefit from various anti-poverty programmes (Government of India Ministry of Rural Development, 2014). There have been four below the poverty line (BPL) censuses in rural India - in 1992, 1997, 2002 and 2011 - the latest is called the Socio-Economic Caste Census (Saxena, 2009). The Planning Commission also set up an Expert Group, chaired by Professor S.R. Hashim, to develop a methodology to identify BPL households in urban areas of India (Government of India, 2012). Table 2 shows the automatic inclusion criteria in rural areas (Government of India Ministry of Rural Development, 2014) and the proposed criteria for urban areas (Government of India, 2012).

\section{$<<<$ TABLE 2 HERE $\gg>$}

In addition, Government of India (2012) proposed that some households could also be classified as BPL in urban areas if they had a high enough score on a range of additional residential, social, and occupational deprivation criteria. The five proposed residential deprivation criteria were:

1. Households living in houses of more than one room with roof of Grass/thatch/bamboo/wood/mud etc. and wall of grass/thatch/bamboo etc. 
2. Households living in houses with roof of handmade tiles or G.I/metal/asbestos sheets and wall of mud/unburnt brick or wood or stone not packed with mortar or G.I/metal/asbestos sheets

3. Household with non-availability of drinking water source within or near the premises

4. Households with main source of lighting other than electricity

5. Households with no exclusive water-seal latrines

\section{Poverty Measurement by the World Bank}

The World Bank’s \$1.25 at PPP (Purchasing Power Parity) a day methodology has also been used to compare poverty in India with other countries (World Bank, 1990; 1996, 2001; Ravallion et al 1991; 2008) and was incorporated into the Millennium Development Goals as a key target. The World Bank's poverty estimates have been heavily criticised (for example see Townsend and Gordon. 2002; Anand, Segal and Stiglitz, 2010), not least for the use of PPP. The international dollar PPP is not a real currency - you cannot buy or hold one - it is a concept. The idea is that, in order to compare the purchasing power of different currencies, a conversion factor (based upon the cost of a basket of goods and services) is required. However, rather than use the exchange rate of money bought and sold in the global currency markets, the World Bank and IMF argue that PPPs should be used since market exchange rates do not reflect the 'true' value of each currency i.e. they are subject to distortions, even if average monthly or yearly rates are used (Gordon and Nandy, 2012).

PPP is difficult to estimate and changes in these estimates can have a dramatic effect on the estimation of poverty rates in India (and in other countries). The International Comparison Program collected price data on the cost of goods and services in about 200 countries and territories and has produced PPP estimates for 2005 and 2011. Chandy and Kharas (2014) have 
shown that the estimated number of $\$ 1.25 \mathrm{PPP}$ a day poor people in India would fall from 400.2 million in 2005 to just 98.9 million in 2009/10 - a huge $75 \%$ fall in poverty in just five years almost entirely as a result of the change in the PPP index estimates.

Thus, PPP and currency exchange rates produce significantly different results when used to compare the incomes of the poor in different countries. In developing countries, consumer goods tend to be relatively cheaper and capital goods relatively more expensive compared with industrialised countries. The PPP conversion reduces/understates the cost of capital goods compared with market exchange rate conversion (Freeman, 2009).

The differences in the extent and depth of child poverty in rich and poor countries are not just a result of households in rich countries having more money. Children in rich countries also have access to an extensive range of capital goods, e.g. schools, hospitals, roads, electricity distribution, water supply infrastructure, sewerage systems, etc. In India, millions of children do not have access to schools, hospitals, safe water, etc. because these capital goods simply do not exist close to where they live. This is important because, by understating the monetary cost of capital goods in developing countries, the PPP conversion, which is an integral part of the $\$ 1.25$ a day poverty methodology, obscures the costs of providing children in India with the services they need to escape from absolute poverty.

In the past, no child poverty estimates have been produced by the World Bank using the $\$ 1.25$ at PPP a day methodology, although this may change during $2015^{\text {iii }}$. There are a number of reasons why the World Bank's poverty methodology will not produce reliable estimates of child poverty in India: 
1. Little is known about the income/expenditure/consumption needs of children in India and how these needs may vary by age, gender and location. Therefore, any income poverty threshold for children would have to be set at an essentially arbitrary level given the current lack of knowledge about Indian children's needs.

2. Household based income 'poverty' analyses usually assume an equal sharing of resources within a household. This assumption is unlikely to be correct as many poor parents may sacrifice their own welfare to try to protect their children.

3. The extent of child poverty is not just dependent on family income, but also on the availability of infrastructure and services, such as health, education and water supply.

4. Internationally agreed definitions of poverty are all concerned with outcomes (e.g. the effects of the lack of command over resources over time).

5. There are many technical problems involved in using an income or expenditure approach to measuring child poverty, for example, calculating equivalent spending power of national currencies over time and region, equivalisation by household type, controlling for infrequent, irregular or seasonal purchases, under-reporting bias and other measurement errors, data discontinuities, quantifying the benefits from 'home' production and the use of durables, etc.

\section{Measuring Child Poverty}

At the beginning of the Millennium, Alberto Minujin and his colleague, Jan Vandemoortele (who was co-architect of the Millennium Development Goals) on behalf of UNICEF commissioned the University of Bristol to develop a methodology to produce scientific estimates of the prevalence and nature of child poverty in developing countries. The methodology had to be based on internationally agreed definitions of poverty and be 
compatible with the framework provided by United Nations Convention on the Rights of the Child and other international human rights agreements. Gordon et al (2003) based their research on the definition of poverty agreed at the 1995 World Social Summit in Copenhagen. The governments of 117 countries defined absolute poverty for policy purposes, as:

"a condition characterised by severe deprivation of basic human needs, including food, safe drinking water, sanitation facilities, health, shelter, education and information. It depends not only on income but also on access to social services." (UN, 1995, p57)

The World Social Summit definition of 'absolute' poverty remains to this day as one of the few internationally agreed definitions of poverty. This 'basic needs' definition of poverty is however very similar to the human rights minimum core obligation. In General Comment 3 the United Nations Economic and Social Council (ECOSOC) determined that there was:

'a minimum core obligation to ensure the satisfaction of, at the very least, minimum essential levels of each of the rights is incumbent upon every State party. Thus, for example, a State party in which any significant number of individuals is deprived of essential foodstuffs, of essential primary health care, of basic shelter and housing, or of the most basic forms of education is, prima facie, failing to discharge its obligations under the Covenant.' (ECOSOC, 1991, para 10) 
In order to measure child poverty based on the World Social Summit definition and in conformity with the human rights minimum core obligation, it is necessary to define the threshold measures of deprivation for each of the component parts of the definition, i.e. to measure absolute poverty requires the identification of thresholds for severe deprivation of basic human need for food, safe drinking water, sanitation facilities, health, shelter, education, information, and access to services.

Relative deprivation theory (Townsend, 1979) conceptualises deprivation as a continuum which ranges from no deprivation, through mild, moderate and severe deprivation to extreme deprivation at the end of the scale (Gordon, 2002). Figure 1 illustrates this concept.

\section{$<<<$ FIGURE 1 HERE $\gg>>$}

Gordon et al (2003) defined 'severe deprivation of basic human need' as those circumstances that are highly likely to have serious adverse consequences for the health, well-being and development of children. Severe deprivations are circumstances which can be causally related to 'poor' developmental outcomes both long and short term.

An idealised taxonomy of child deprivation was produced identifying thresholds of different levels of severity (see Gordon et al, 2003 for details) and this was subsequently operationalized as far as practicable, using widely available data e.g. India's National Family Health Surveys (NFHS). Two such operational thresholds levels for each indicator were used by UNICEF in the subsequent Global Study of Child Poverty and Disparities ${ }^{\text {iv }}$ (see Table 2) to measure child poverty in over 50 low and middle income countries. 
A semi-systematic literature review helped to identify potential child deprivation indicators and thresholds which had been used in previous studies as good measures of child poverty. Subsequent work can be found in Nandy et al (2005), Pemberton et al (2005, 2007, 2012), Nandy and Miranda (2008), Nandy and Gordon (2009), Nandy (2010), Gordon, Lenoel and Nandy (2012), Gordon and Nandy (2012) and Halleröd et al (2013).

The purpose of Gordon et al (2003) was to measure children's living conditions that are so severely deprived that they are indicative of absolute poverty. Thus, the deprivation thresholds used represent more severe deprivation than the indicators frequently published by international organisations. For example, 'no schooling' instead of 'non-completion of primary school', 'no sanitations facilities' instead of 'unimproved sanitations facilities', 'no immunisations of any kind' instead of 'incomplete immunisation against common diseases', 'malnutrition measured as anthropometric failure below -3 standard deviations from the reference population median' instead of 'below -2 standard deviations from the reference median', etc. It should also be noted that several of the severe child deprivation criteria (second column Table 3) are similar in nature, but more severe, than the deprivation criteria used in India to identify Below Poverty Line (BPL) families (see Table 2). In all cases, a concerted attempt was made to err on the side of caution in defining these indicators of deprivation of basic human need. By using such severe thresholds few could question that these living conditions were unacceptable.

Children who suffer from any severe deprivation of basic human need are very likely to be living in absolute poverty because, in the overwhelming majority of cases, the cause of their severe deprivation is invariably the result of lack of resources/income. However, there may also be some children in this situation due to discrimination (e.g. girls suffering severe 
education deprivation) or due to disease (severe malnutrition can be caused by some diseases). For this reason, Gordon et al (2003) assumed that a child is living in absolute poverty only if he or she suffers from two or more severe deprivations of basic human need as defined in Table 3 (see last column). This approach was adopted by UNICEF (and also other researchers around the world), and formed a key part of UNICEF's Global Study on Child Poverty and Disparities.

\section{$<<<$ TABLE 3 HERE $\gg>>$}

\section{Child Poverty in India}

The results from the analyses of India's 2005/06 NFHS data show that:

- Over two-thirds (68\%, around 300 million) of Indian children live in dwellings with more than five people per room or which have a mud floor;

- Over a quarter of a billion Indian children (62\%, 272 million) have no toilet facilities whatsoever;

- Over 30 million Indian children (7\%) are using unsafe (open) water sources or have more than a 30 minute walk to collect water;

- About one Indian child in seven (61 million) lacks access to radio, television, telephone or newspapers at home;

- $27 \%$ of Indian children under five are severely food deprived (severe anthropometric failure);

- $13 \%$ of Indian children under five have not been immunised against any diseases or have had a recent illness causing diarrhoea and have not received any medical advice or treatment; and

- $13 \%$ of Indian children aged between 7 and 17 (around 34 million) are severely educationally deprived - they reported never having been to school. 
In 2005/06, over half (58\%) of India's children (256 million) were living in absolute poverty, that is severely deprived of two or more basic human needs; over 350 million children were severely deprived of one or more basic needs. This analysis shows that very large numbers of children (aged under 18) were suffering from severe deprivation compared with the total numbers of poor as estimated by the Tendulkar (2009) methodology (270 million) or the World Bank \$1.25 PPP methodology (400 million). This suggests both these methods significantly underestimate the poverty of children, and also their families.

It is relevant for policy purposes to examine both the prevalence of each type of deprivation, and also how they overlap. Table 4 shows that over half the children of India (52\%) suffered from both shelter and sanitation deprivation. The second most frequent combination of deprivations was shelter and food deprivation (malnutrition) which affected $22 \%$ of children in India. Health and education deprivation are also frequently found in combination, which highlights the problem of service receipt in India.

\section{$<<<$ TABLE 4 HERE $>>$}

There are many studies of poverty in India, particularly by economists, which examine the associations between poverty and individual characteristics (e.g. education level, gender, health/disability, etc.). It is not possible to provide a comprehensive overview of the demographic, social, economic, geographic and cultural distribution of child poverty in a single short paper. Since much is already know about individual level associations with poverty, this paper examines instead the social, cultural and geographic distribution of child poverty in India. These kinds of distributions are often the result of structural causes of poverty. 
In most countries, it is very rare for people to be born, live and die in poverty and for their children to do likewise. The conditions of poverty are often unpleasant, from which people invariably try to escape; in most modern societies there is sufficient social mobility and opportunity for them to succeed - at least for part of their life. It usually takes a vigorously policed and socially enforced structural cause to keep people poor for long periods of time one such structure may be the Caste system in India. There is a large literature which shows that Dalits (Scheduled Castes) and the Adivasis (Scheduled Tribes) constitute a large proportion of the 'poor', in both rural (Ravallion and Datt 2002; Gang et al 2008) and urban areas (Madheswaran and Attewell 2007).

Dalits and religious minorities like Muslims in India often suffer from economic discrimination, in both the labour market (restricted job opportunities) and in access to nonmarket services, such as health care, education, fair price shops, etc. (Thorat and Neuman, 2012). In many countries poor people can sometimes work their way and/or marry their way out of poverty, but caste systematically restricts job opportunities and prevents inter-marriage, effectively reducing both social and geographic mobility (Munshi and Rosenzweig, 2006, 2009). Genetic studies have shown that the modern Indian population is largely descended from two broad ancestral populations, called the 'Ancestral North Indians' (ANI) - which is genetically close to Middle Easterners, Central Asians, and Europeans - and the 'Ancestral South Indians' (ASI), which is distinct to India (Reich et al, 2009). The DNA evidence from 571 individuals from 73 well-defined ethno-linguistic groups shows that Indian men and women mixed freely and had children together across ethno-linguistic groups for most of Indian history. However, about 1,900 years ago, when the caste system was codified, this genetic intermixing ceased: 
'India experienced a demographic transformation during this time, shifting from a region where major mixture between groups was common and affected even isolated tribes such as the Palliyar and Bhil to a region in which mixture was rare.' (Moorjani et al, 2013, p429)

Historians, have argued that the caste system in India has developed and evolved over time and extended and strengthened during the $18^{\text {th }}$ and $19^{\text {th }}$ Centuries (Bayly 1999). Thus, it is important to look at the geographic, social and cultural distribution of child poverty in India to examine the associations between these factors. Unfortunately, there are still massive differences by state in the likelihood of an Indian child living in absolute poverty (Figure 2). In Kerala only $4 \%$ of children suffer from absolute child poverty - a child from Kerala is four times less likely to be poor than a child in Delhi. By contrast there are five Indian states where more than seven out of every ten children are living in absolute poverty.

\section{$<<<$ FIGURE 2 HERE $\gg>$}

There is no clear geographic pattern to the high child poverty states - although there are fewer central states in this group and high poverty rates in the northern (BIMARU) states.

Unsurprisingly, absolute child poverty in India not only varies by geographical location it also varies by social and cultural group. Historically, caste group has been one of the major social divisions in Indian society and despite many attempts to minimise the effects of caste on living standards this division persists (Figure 3). More than eight out of ten children from Scheduled Tribal groups are absolutely poor compared with less than four in ten children from higher caste groups - a more than two fold difference. 


\section{$<<<$ FIGURE 3 HERE $\gg>>$}

Caste divisions in Indian society are mainly (but not exclusively) confined to Hindu communities. Therefore it is also interesting to examine the distribution of absolute child poverty by religious affiliation (Figure 4). Standard of living differences by religion are considerably greater than between caste groups. Secular families and those from 'other' religions have absolute child poverty rates of $76 \%$ and $80 \%$ respectively. By contrast children from Jain families are very unlikely to suffer from absolute poverty (prevalence rate $=6 \%$ ). This result may be surprising as Jain monks and nuns own no property and possess few worldly goods and it is a key principal of Jainism to engage in acts of kindness, compassion and charity. By contrast secularism requires no renunciation of worldly goods or acts of charity. However it should also be noted that Jains make up a significant section of India's most vibrant business communities.

\section{$<<$ FIGURE 4 HERE $\gg>$}

An additional important social and cultural division in India is language (Figure 5). The national Census recorded that over 1,500 languages were spoken in India and that 22 languages are recognised in the Indian Constitution as scheduled languages.

\section{$<<<$ FIGURE 5 HERE $\gg>$}

Oriya is the linguistic group with the highest absolute child poverty rates (69\%), followed by Hindi (67\%), while Malayalam has the lowest (4\%). Children in two out of five families who reported speaking English at home are absolutely poor, which is lower than average absolute 
child poverty rate $(58 \%)$, but it is similar to the rates found amongst Tamil speakers. The relatively low rates of absolute child poverty in Kashmiri speaking families is surprising, given the devastation caused to the local economy in Kashmir by the October 2005 earthquake although most of the deaths from this disaster occurred in Pakistan rather than in India.

\section{Malnutrition in India}

One of the most important results from analysis of the 2005/06 NFHS is the persistence of very high rates of extreme malnutrition amongst young children (under 5) in India. Severe malnutrition can result in life-long consequences that include short-stature (stunting), susceptibility to disease and impaired cognition. Laus et al (2011) argue that;

'there is overwhelming evidences that malnutrition, especially imposed in early life, has significant and lasting implications for the development of cognition both in humans and animals' and 'Malnutrition has been recognized to cause reductions in the numbers of neurons, synapses, dendritic arborization, and myelination, all of which result in decreased brain size. Also, the cerebral cortex is thinned and brain growth slowed. All these central nervous system alterations are associated with delays in motor and cognitive functions, such as attention deficit disorder, impaired school performance, decreased IQ scores, memory and learning deficiencies, and reduced social skills' (Laus et al, 2011, p607, p591).

Given these life-long detrimental consequences of severe malnutrition it is important to investigate the changes which have occurred in India.

Data from India's National Family Health Survey (NFHS), conducted in 1992/3, 1998/99, and 2005/06, show that there was little progress in reducing child malnutrition. Anthropometric 
data between the surveys are not strictly comparable, ${ }^{\mathrm{v}}$ and administrative changes to state boundaries means like for like sub-national comparisons are problematic. Also, a growing body of work shows that conventional indicators of undernutrition, i.e. stunting, wasting and underweight, each on its own, fails to capture the overall prevalence of undernutrition, and researchers increasingly use an alternative measure, the Composite Index of Anthropometric Failure (CIAF) (Svedberg 2000; Nandy et al. 2005; Svedberg 2007; Nandy and Miranda 2008). The CIAF, briefly, identifies (without double counting) children who experience either stunting, wasting and/or underweight i.e. those children who are more than two standard deviations below the international reference population for stunting (height for age) or wasting (weight for height) or underweight (weight for age) (see first 1 in Table 3). Table 5 presents national estimates for India, of anthropometric failure for children aged 0 to 35 months, for 1998/99 and 2005/06. More up to date estimates are not possible given a lack of nationally representative surveys, although NFHS4 is ongoing until June 2016.

\section{$<<<$ TABLE 5 HERE $\gg>>$}

The data presented in Table 5 are means, with upper and lower 95\% confidence intervals. Where upper and lower bounds do not overlap, changes over time are statistically significant; where they do overlap observed changes are not statistically significant. The same applies to differences between groups (e.g. boys vs girls, etc) within survey years.

At the national level there was a small decline in undernutrition among young children, from 64\% to 61\% between 1999 and 2006; a majority of young children in India in 2006 were therefore clinically malnourished. The prevalence of undernutrition among children in rural areas was high, with around two-thirds affected; in urban areas, the picture was not much better, 
with over a half of all children being malnourished. The reduced prevalence for urban children was not statistically significant. Gender differences in nutritional status in India are frequently reported as being pronounced, but often this is due to the choice of indicator, with boys more likely to experience wasting, and girls more likely to experience stunting and/or underweight. However the CIAF shows that in terms of aggregate undernutrition, gender differences in each round were not large or significant, with roughly equal proportions of girls and boys experiencing anthropometric failure.

A significant source of disparity observed in nutritional status observed is childrens' caste or tribe (see also Kumar and Singh, 2013). Members of India's Scheduled Caste and Scheduled Tribe communities have historically been (and continue to be) particularly disadvantaged with regards a range of outcomes, including poverty, social and material deprivation, and access to basic services and entitlements. In terms of nutritional status, around three-quarters (74\%) of Scheduled Tribe children were malnourished in 1999. This figure had fallen to $69 \%$ by 2005/06, and remains a damning indictment of India's ability, capacity and willingness to meet even the most basic food needs of many of its most deprived children. Meaningful progress was made in reducing undernutrition but only among children from higher caste or nonSC/ST/OBC groups, who already had the lowest rates of prevalence. This suggests a growing inequality between 1999 and 2006, which cannot bode well for the future, given wellestablished links between poor nutrition, child health, development and survival.

It is important to note that the marked inequalities in the prevalence of malnutrition by caste group and rural/urban residence (discussed above) contradict analyses by Subramanyam et al (2010) who argued that 'There were no disparities in undernutrition by caste, gender or rural residence' (e11392). Unfortunately, their published analyses appears to have been affected by 
a coding error and the predicted probabilities and 95\% confidence intervals reported for underweight children (in their Table 2) are identical for both 1998 and 2005/06 NFHS - this is statistically improbable.

The lower half of Table 5 shows how malnutrition is patterned in India. In both rounds, the most prevalent forms of undernutrition are a combination of stunting and underweight. Worryingly, the proportion of children who experience a triple anthropometric failure or deficit (i.e. simultaneously experiencing stunting, wasting and underweight) did not change between $1998 / 99$ and 2005/06. At 10\%, of all children, or $15 \%$ (one in seven) of children with an anthropometric failure, this implies tens of millions of Indian children face increased risks of morbidity and early mortality. Recent research by McDonald et al. (2013) showed that children with a triple deficit had a twelve-time greater risk of early mortality than children with no failures. The implications of this for child well-being in India are clear, not least with regards the failure to meet the MDG relating to child mortality (see Table 1).

\section{How does malnutrition in India compare with other 'poor' countries?}

Nearly twenty years ago UNICEF asked why it was that despite being relatively wealthier than most countries in sub-Saharan Africa, the countries of South Asia, and in particular India and Bangladesh, had far higher rates of child malnutrition. This counter-intuitive situation was termed the 'Asian Enigma' (Ramalingaswami, Jonsson \& Rohde, 1996). South Asia's higher prevalence of malnutrition could not be explained by levels of agricultural production, the relative levels of poverty and inequality within countries, types of diet, access to medical care, or government neglect. Two factors which might explain the differences were the relative status of women, and access to water and sanitation which ensured basic hygiene. 
The status of women and girls in India today is unarguably poor, with girls much more likely to be deprived of a secondary education ${ }^{\mathrm{vi}}$, to marry younger, to face gender violence and control, and even to be subject to sex-selective abortion by families who would prefer a son (UNICEF, 2011). As this paper shows, children in India are still exposed in huge numbers to real problems of water, sanitation and shelter deprivation. Squalid living conditions will, just as they did 20 years ago, drive and sustain high rates of malnutrition (see Table 3), which in turn will contribute to higher rates of child morbidity and premature mortality.

Table 6 shows little has changed since the mid-1990s with regard to the extent of malnutrition in South Asia relative to sub-Saharan Africa. Countries with lower levels of income per capita, like Ethiopia and Ghana, have far lower rates of malnutrition than India. Even countries like Bangladesh, which lack India's resources, have successfully reduced child malnutrition to below the levels found in India. Progress, it seems, is possible where there is sufficient political will.

\section{$<<<$ TABLE 6 HERE $>>>$}

\section{Conclusions}

A number of conclusions can be drawn from these analyses. Firstly, large numbers of children in India live in poor conditions due to high rates of shelter, sanitation \& water deprivation particularly in rural areas and urban slums. Although good progress has been made with improving access to improved water sources (see Table 1), progress has been much slower in improving sanitation and housing conditions. 
One consequence of this lack of progress is that child malnutrition rates remain high in India and this is likely to have long term detrimental consequences for the children themselves, their families and the Indian economy. Severe malnutrition in particular can result in life long physical and mental health problems.

Information deprivation is often missing from the policy agenda, yet it is likely to become increasingly important during the 21st Century. A digital divide is evident in India with some children having access to the internet and a wealth broadcast and social media, whereas poor children may not even be able to regularly listen to a radio.

Social protection programmes need to be expanded particularly health and education programmes. Despite the progress that has been made, too many children in India still have little or no contact with medical services, and many never get to attend or stay in school.

Child/family benefit programmes need to be introduced and expanded across India. They are relatively inexpensive and have been shown to be very effective at reducing child poverty, for example Brazil's Bolsa Familia and Mexico's PROGRESSA programmes (Hanlon 2004; Hanlon et al, 2010). India could quite easily commit to implementing a minimum social protection floor ${ }^{\mathrm{vii}}$. In 1948, the United Nations agreed that social security and health care for children, working age people who face unemployment or injury and older persons are a universal human right (ILO 2014). More recently, the ILO's Social Protection Floor Recommendations, 2012 (No. 202) ) $^{\text {viii }}$, were agreed by the governments and employers' and workers' organizations from 185 countries. 
The ILO (2014) argues that National social protection floors should comprise at least the following four social security guarantees, as defined at the national level ${ }^{\mathrm{ix}}$ :

1. access to essential health care, including maternity care.

2. basic income security for children, providing access to nutrition, education, care and any other necessary goods and services.

3. basic income security for persons in active age who are unable to earn sufficient income, in particular in cases of sickness, unemployment, maternity and disability; and 4. basic income security for older persons.

Finally, as the pattern of severe deprivation varies within and between states in India, it is therefore necessary that different policy packages be developed and applied in different areas to target the problems which have the greatest harmful effects on children's lives. As noted above, this paper is limited by the fact that the data used are dated (collected in 2005/06), and we acknowledge that considerable improvements to people's living standards may well have been made in the ten years since the last NFHS. Assessment of these changes, and their nature (have improvements been equitable or otherwise) will be possible when the current round of NFHS data are released later this year. 


\section{References}

Anand, S., Segal, P. \& Stiglitz, J.E. (2010) Debates on the measurement of global poverty. Oxford University Press, New York.

ASER (2015) Annual Status of Education Report 2014: Main Findings. New Delhi, ASER Centre/Pratham.

http://img.asercentre.org/docs/Publications/ASER\%20Reports/ASER\%202014/Nationa 1\%20PPTs/aser2014indiaenglish.pdf

Bayly, S. (1999) Caste, society and politics in India: from the eighteenth century to the modern age. Cambridge: Cambridge University Press.

Central Statistics Office (2012) Children in India 2012- A Statistical Appraisal. New Delhi, Government of India.

Chandy, C. and Kharas, H. (2014) What Do New Price Data Mean for the Goal of Ending Extreme Poverty? Washington, Brookings Institute.

www.brookings.edu/blogs/up-front/posts/2014/05/05-data-extreme-poverty-chandy$\underline{\text { kharas }}$

Deaton, A. and Kozel.V. (2005a) (Eds) The Great Indian Poverty Debate. New Delhi, Macmillan India.

Deaton, A. and Kozel.V. (2005b) Data and dogma: the great Indian poverty debate. World Bank Research Observer, 20 (2):177-99.

ECOSOC (Committee on Economic, Social and Cultural Rights) (1991) General Comment 3, The nature of States parties' obligations. Report on the Fifth Session, Supp. No. 3, Annex III, U.N. Doc. E/1991/23.

Freeman, A. (2009) The Poverty of Statistics and the Statistics of Poverty. Third World Quarterly, Vol. 30, No. 8, 1427-1448.

Gang, I., Yun, M. and Sen. K. (2008) Poverty in rural India: caste and tribe. Review of Income and Wealth, 54, 1, 50-70

Gordon, D. (2002) The international measurement of poverty and anti-poverty policy. In Townsend, P. and Gordon, D. (Eds) World Poverty: New Policies to Defeat an Old Enemy. Bristol. Policy Press, pp 53-80.

Gordon, D., Nandy, S., Pantazis, C., Pemberton, S. and Townsend, P. (2003) Child Poverty in the Developing World, Policy Press: Bristol. 
Gordon, D. (2004) Poverty, Death \& Disease. In Hillyard, P., Pantazis, C., Tombs, S. and Gordon, D. (eds.) (2004) Beyond Criminology: Taking Harm Seriously. London, Pluto. pp 251-266

Gordon, D. and Nandy, S. (2012) Measuring child poverty and deprivation. In Minujin, A. and Nandy, S. (Eds) Global Child Poverty and Well-Being: Measurement, Concepts, Policy and Action. Bristol, Policy Press. pp 57-101.

Gordon, D., Lenoel, A. and Nandy, S. (2012) Multidimensional child poverty in Haiti. . In Minujin, A. and Nandy, S. (Eds) Global Child Poverty and Well-Being: Measurement, Concepts, Policy and Action. Bristol, Policy Press. pp 357-377.

Gordon, D. (2015) Foreword: Child Poverty. In Fernandez, E., Zeira, A., Vecchiato, T. and Canali, C. (eds) Theoretical and Empirical Insights into Child and Family Poverty: Cross National Perspectives. Springer. Pp 3-7.

Government of India Planning Commission (2009), Report of the Expert Group to Review the Methodology for Estimation of Poverty, Chaired by S.D. Tendulkar, Government of India, New Delhi.

Government of India Planning Commission (2012) Report of the Expert Group to Recommend the Detailed Methodology for Identification of Families Living Below the Poverty Line in Urban Areas (Hashim Report). Government of India, New Delhi. http://planningcommission.nic.in/reports/genrep/rep_hasim1701.pdf

Government of India Ministry of Rural Development (2014) Annual Report 2013-14. Ministry of Rural Development, Government of India, New Delhi.

Government of India Planning Commission (2014) Report of the expert group to review the methodology for measurement of poverty (Rangarajan Report). New Delhi. http://planningcommission.nic.in/reports/genrep/pov_rep0707.pdf

Halleröd, B, Rothstein, B, Nandy, S \& Daoud, A, (2013) Bad governance and poor children: a comparative analysis of government efficiency and severe child deprivation in 68 lowand middle-income countries. World Development, 48, pp. 19-31.

Hanlon, J. (2004) Is it Possible to Just Give Money to the Poor, Development and Change, $35,2,375-383$.

Hanlon, J., Barrientos, A., and Hulme, D. (2010) .Just Give Money to the Poor: The Development Revolution from the Global South. Herndon, Kumarian Press 
Himanshu and Sen, K. (2014) Revisiting the Great Indian Poverty Debate: Measurement, Patterns, and Determinants. Brooks World Poverty Institute Working Paper 203.

ILO (2014) World Social Protection Report 2014-15: Building economic recovery, inclusive development and social justice. Geneva: ILO.

www.ilo.org/global/research/global-reports/world-social-securityreport/2014/WCMS_245201/lang--en/index.htm

Joshi, P. (1997) Conceptualisation, Measurement and Dimensional Aspects of Poverty in India, Presentation to the First Meeting of the UN Expert Group on Poverty Statistics (Rio Group).

www.ibge.gov.br/poverty/pdf/india.pdf

Kumar A, and Singh, A. (2013) Decomposing the Gap in Childhood Undernutrition between Poor and Non-Poor in Urban India, 2005-06. PLoS ONE 8(5): e64972. doi:10.1371/journal.pone.0064972

Laus, M.F., Vales, L., Costa, T. and Almeida, S. (2011) Early Postnatal Protein-Calorie Malnutrition and Cognition: A Review of Human and Animal Studies. International Journal of Environmental Research and Public Health, 8(2), 590-612; doi:10.3390/ijerph8020590

Madheswaran, S. and Attewell. P, (2007) Caste discrimination in the Indian urban labour market: evidence from the national sample survey. Economic and Political Weekly, 13 October: 4146-53.

McDonald, C. M., I. Olofin, et al. (2013). The effect of multiple anthropometric deficits on child mortality: meta-analysis of individual data in 10 prospective studies from developing countries. American Journal of Clinical Nutrition 97(4): 896-901.

Minujin A., Delamonica, E.E. Davidziuk A. and Gonzalez E.D. (2006) The definition of child poverty: a discussion of concepts and measurements. Environment \& Urbanization, 18 (2), 481-500

Minujin, A \& Nandy, S. (2012) (Eds.) Global child poverty and well-being: Measurement, concepts, policy and action, Bristol: The Policy Press

Moorjani, P., Thangaraj, K., Patterson, N., Lipson, M., Loh, P.R., et al. (2013) Genetic evidence for recent population mixture in India. American Journal of Human Genetics, 93: $422-438$ 
Munshi, K. and Rosenzweig, M. (2006) Traditional Institutions Meet the Modern World: Caste, Gender and Schooling Choice in a Globalizing Economy. American Economic Review. 96(4): 1225-1252.

Munshi, K. and Rosenzweig, M. (2009) Why is Mobility in India So Low? Social Insurance, Inequality, and Growth. NBER Working Paper 14850 http://www.nber.org/papers/w14850

Nandy, S., Irving, M., Gordon, D., Subramanian. S.V. and Davey Smith, D. (2005) Poverty, child undernutrition and morbidity: new evidence from India. Bulletin of the World Health Organisation, 83, 3, 210-216.

Nandy, S. and Miranda, J. (2008). Overlooking undernutrition? Using a composite index of anthropometric failure to assess how underweight misses and misleads the assessment of undernutrition in young children. Social Science and Medicine 66(9): 1963-1966.

Nandy, S. and Gordon, D. (2009) Children Living in Squalor. Shelter, Water and Sanitation Deprivations in Developing Countries Children, Youth \& Environment. 19, 2, 202-228.

Panagariya, A. and Mukim, M. (2013) A Comprehensive Analysis of Poverty in India, World Bank Policy Working Paper no. 6714.

Pemberton, SA, Gordon, D, Nandy, S, Pantazis, C \& Townsend, PB. 'The Relationship between Child Poverty and Child Rights: The Role of Indicators', in Minujin, A, Delamonica, E and Komarecki, M (Eds.), Human rights and social policies for children and women: The Multiple Indicator Cluster Survey (MICS) in Practice, (pp. 47-61), NY: New School University.

Pemberton, S., Gordon, D., Nandy, S., Pantazis, C. and Townsend, P. (2007) Child Rights and Child Poverty: Can the International Framework of Children's Rights Be Used to Improve Child Survival Rates? PLoS Medicine. 4(10): e307. Published online 2007 October 23. doi: 10.1371/journal.pmed.0040307

Pemberton, S., Gordon, D., and Nandy, S. (2012) Child rights, child survival and child poverty: the debate. In Minujin, A. and Nandy, S. (Eds) Global Child Poverty and Well-Being: Measurement, Concepts, Policy and Action. Bristol, Policy Press. pp 19-37.

Ramalingaswami, V., Jonsson, U. and Rohde, J. (1996). Commentary: The Asian Enigma. The Progress of Nations 1996. New York, UNICEF. 
Ravallion, M., G. Datt and D. Van de Walle (1991). Quantifying absolute poverty in the developing world, Review of Income and Wealth 37(4): 345-361.

Ravallion, M. and Datt. G. (2002) Why has economic growth been more pro-poor in some states of India than others? Journal of Development Economics, 68: 381-400

Ravallion, M., S. Chen and P. Sangraula (2008). Dollar a day revisited. Policy Research Paper. Washington DC, World Bank.

Ray, R and Sinha, K (2014), Rangarajan Committee Report on Poverty Measurement, Economic and Political Weekly, Vol XLIX (32).

Reich, D., Thangaraj, K., Patterson, N., Price, A.L., and Singh, L. (2009). Reconstructing Indian population history. Nature, 461, 489-494.

Saxena, N. C. (2009) Report of the Expert Group to Advise the Ministry of Rural Development on the Methodology for Conducting the Below Poverty Line (BPL) Census for 11th Five-Year Plan, , New Delhi, Ministry of Rural Development, Government of India.

Stierli, M., Shorrocks, A., Davies, J., Lluberas, R. and Koutsoukis, A. (2014) Global Wealth Report 2014. Zurich, Credit Suisse A.G

Subramanyam MA, Kawachi I, Berkman LF, Subramanain SV (2010) Socioeconomic inequalities in childhood under-nutrition in India: Analysing trends between 1992 and 2005. PLoS One 5 ((6)): e11392 doi:10.1371/journal.pone.0011392.

Svedberg, P. (2000). Poverty and Undernutrition: Theory, Measurement and Policy. Oxford, Oxford University Press.

Svedberg, P. (2007). Can Indicators of Child Malnutrition be Improved-And For What Purposes? Taking Action for the World's Poor and Hungry People. Beijing, China.

Thorat, S. and Neuman, K. (2012) Blocked by Caste Economic Discrimination in Modern India. Delhi, OUP India

Townsend, P. (1979) Poverty in the United Kingdom, London, Allen Lane and Penguin Books

Townsend, P. and Gordon, D. (eds) (2002) World Poverty: New Policies to Defeat an Old Enemy. Bristol. Policy Press

UNICEF (2009) UNICEF mourns death of Professor Peter Townsend. Press Release, UNICEF, New York www2.unicef.org:60090/media/media_49993.html 
UNICEF (2011) The Situation of Children In India. New Delhi, UNICEF India.

United Nations (1995) The Copenhagen Declaration and Programme of Action: World Summit for Social Development 6-12 March 1995. New York, United Nations.

United Nations Economic \& Social Council [ECOSOC] (1991) Committee on Economic, Social \& Cultural Rights, Report on the Fifth Session, Supplement No. 3 , Annex III, 10, U.N. Doc. E/1991/23 [Often referred to as General Comment No. 3]

World Bank (1990) World Development Report 1990: Poverty. NewYork, Oxford University Press. 


\section{Tables and Figures}

Table 1: Millennium Development Goals (MDG) Progress in India

\begin{tabular}{|c|c|c|}
\hline \multicolumn{3}{|l|}{ Are we there yet? } \\
\hline Target & & \\
\hline Poverty: halve the proportion of people living in extreme poverty & $\begin{array}{l}1990 \\
\mathbf{4 8 \%}\end{array}$ & 2012 \\
\hline Hunger: halve the proportion of hungry people & 1990 & $\begin{array}{l}2006 \\
\mathbf{4 0 \%}\end{array}$ \\
\hline Education: ensure all children can complete primary school & 1990 & $\begin{array}{l}2011 \\
97 \%\end{array}$ \\
\hline Gender equality: end gender disparities in schools* & $\begin{array}{l}1990 \\
\mathbf{0 . 7 6}\end{array}$ & $\begin{array}{l}2011 \\
1.02\end{array}$ \\
\hline Child mortality: cut under- 5 mortality rate (per 1,000 live births) by two thirds & 1990 & $\begin{array}{l}2013 \\
53\end{array}$ \\
\hline $\begin{array}{l}\text { Maternal mortality: cut maternal mortality rate (per 1,000 live births) by three } \\
\text { quarters }\end{array}$ & $\begin{array}{l}1990 \\
560\end{array}$ & $\begin{array}{l}2013 \\
190\end{array}$ \\
\hline $\begin{array}{l}\text { Tuberculosis (TB): halve and begin to reverse the incidence of malaria and other } \\
\text { major diseases** }\end{array}$ & $\begin{array}{l}1990 \\
\mathbf{4 6 5}\end{array}$ & $\begin{array}{l}2011 \\
230\end{array}$ \\
\hline Water: halve the proportion of people without access to safe drinking water & $\begin{array}{l}1990 \\
\mathbf{3 0 \%}\end{array}$ & $\begin{array}{l}2012 \\
7 \%\end{array}$ \\
\hline Sanitation: halve the proportion of people without access to basic sanitation & $\begin{array}{l}1990 \\
82 \%\end{array}$ & $\begin{array}{l}2012 \\
64 \%\end{array}$ \\
\hline $\begin{array}{l}\text { * Gender Parity Ration for Primary School; ** TB rate per } 100,000 \text { people } \\
\text { Source http://mdgs.un.org/unsd/mdg/data.aspx } \\
\text { Shaded cells show targets either met or likely to be met by } 2015\end{array}$ & & \\
\hline
\end{tabular}


Table 2: Inclusion criteria for Below Poverty Line Families

\begin{tabular}{|l|l|}
\hline \multicolumn{1}{|c|}{ Urban } & \multicolumn{1}{|c|}{ Rural } \\
\hline Automatic inclusion criteria & Automatic inclusion criteria \\
\hline Household is 'houseless' & Households without shelter \\
\hline Household has no income from any source & Destitute/living on alms \\
\hline $\begin{array}{l}\text { Any household member (including children) who } \\
\text { is engaged in a vulnerable occupation like } \\
\text { beggar/rag picker, domestic worker (who are } \\
\text { actually paid wages) and sweeper/sanitation } \\
\text { worker /gardener) }\end{array}$ & Manual scavengers \\
\hline $\begin{array}{l}\text { If all earning adult members in a household are } \\
\text { daily wagers or irregular wage earners }\end{array}$ & Legally released bonded labourers \\
\hline & Primitive Tribal Groups \\
\hline Deprivation indicator criteria & Deprivation indicator criteria \\
\hline $\begin{array}{l}\text { Household has a house of only one room or less } \\
\text { with the material of wall being grass, thatch, } \\
\text { bamboo, mud, un-burnt brick, wood or } \\
\text { plastic/polythene and the material of roof being } \\
\text { grass, thatch, bamboo, wood, mud wood or } \\
\text { plastic/polythene }\end{array}$ & $\begin{array}{l}\text { Households with only one room with kuccha } \\
\text { walls and kuccha roof }\end{array}$ \\
\hline $\begin{array}{l}\text { Child-headed household i.e. if there is no member } \\
\text { of the household aged 18 years and above. }\end{array}$ & $\begin{array}{l}\text { Households with no adult member between } \\
\text { age16 and 59 }\end{array}$ \\
\hline $\begin{array}{l}\text { If there is no able-bodied person aged between } 18 \\
\text { and 60 years in the household, i.e. all members of } \\
\text { the household aged between } 18 \text { and } 60 \text { years } \\
\text { either have a disability or are chronically ill }\end{array}$ & $\begin{array}{l}\text { Households with disabled member and no able } \\
\text { bodied adult member }\end{array}$ \\
\hline $\begin{array}{l}\text { If all earning adult members in a household are } \\
\text { either disabled, chronically ill or aged more than } \\
\text { 65 years }\end{array}$ & $\begin{array}{l}\text { Female headed households with no adult male } \\
\text { member between age 16 and 59 }\end{array}$ \\
\hline & Scheduled Caste/Scheduled Tribe households \\
\hline & $\begin{array}{l}\text { Landless households deriving a major part of } \\
\text { their income from manual casual labour }\end{array}$ \\
\hline \begin{tabular}{l} 
Households with no literate adult above 25 years \\
\hline
\end{tabular}
\end{tabular}


Table 3: Thresholds used in UNICEF's Global Study on Child Poverty and Disparities

\begin{tabular}{|c|c|c|}
\hline Deprivation & Thresholds for 'less severe deprivation' & Thresholds for 'severe deprivation' \\
\hline Shelter & $\begin{array}{l}\text { Children living in dwellings with } 4 \text { or more } \\
\text { people per room or living in a house with no } \\
\text { flooring (i.e. a mud or dung floor) or } \\
\text { inadequate roofing. }\end{array}$ & $\begin{array}{l}\text { Children living in a dwelling with } 5 \text { or more } \\
\text { people per room or with no floor material. }\end{array}$ \\
\hline Sanitation & $\begin{array}{l}\text { Children using unimproved sanitation } \\
\text { facilities. Unimproved sanitation facilities } \\
\text { include: pour flush latrines; covered pit } \\
\text { latrines; open pit latrines; and buckets. }\end{array}$ & $\begin{array}{l}\text { Children with no access to a toilet facility of } \\
\text { any kind. }\end{array}$ \\
\hline Water & $\begin{array}{l}\text { Children using water from an unimproved } \\
\text { source such as open wells, open springs or } \\
\text { surface water or where it takes } 30 \text { minutes or } \\
\text { longer to collect water (walk to the water, } \\
\text { collect it and return). }\end{array}$ & $\begin{array}{l}\text { Children using surface water such as rivers, } \\
\text { ponds, streams and lakes, or where it takes } 30 \\
\text { minutes or longer to collect water (walk to } \\
\text { the water, collect it and return). }\end{array}$ \\
\hline Information & $\begin{array}{l}\text { Children (aged 3-17 years) with no access to } \\
\text { a radio or television (i.e. broadcast media). }\end{array}$ & $\begin{array}{l}\text { Children (aged 3-17 years) with no access to } \\
\text { a radio, television, telephone, newspaper or } \\
\text { computer (i.e. all forms of media). }\end{array}$ \\
\hline Food & $\begin{array}{l}\text { Children who are more than two standard } \\
\text { deviations below the international reference } \\
\text { population for stunting (height for age) or } \\
\text { wasting (weight for height) or underweight } \\
\text { (weight for age). }\end{array}$ & $\begin{array}{l}\text { Children who are more than three standard } \\
\text { deviations below the international reference } \\
\text { population for stunting (height for age) or } \\
\text { wasting (weight for height) or underweight } \\
\text { (weight for age). This is also known as severe } \\
\text { anthropometric failure. }\end{array}$ \\
\hline Education & $\begin{array}{l}\text { Children (aged 7-17) of school age not } \\
\text { currently attending school or who did not } \\
\text { complete their primary education. }\end{array}$ & $\begin{array}{l}\text { Children (aged 7-17) of school age who have } \\
\text { never been to school and who are not } \\
\text { currently attending school. }\end{array}$ \\
\hline Health & $\begin{array}{l}\text { Children who have not been immunised by } 2 \\
\text { years of age. If the child has not received } \\
\text { eight of the following vaccinations they are } \\
\text { defined as deprived: BCG, DPT1, DPT 2, } \\
\text { DPT 3, Polio0, Polio1, Polio2, Polio3, } \\
\text { Measles or did not receive treatment for a } \\
\text { recent illness involving an acute respiratory } \\
\text { infection or diarrhoea. }\end{array}$ & $\begin{array}{l}\text { Children who did not receive immunization } \\
\text { against any diseases or who did not receive } \\
\text { treatment for a recent illness involving an } \\
\text { acute respiratory infection or diarrhoea. }\end{array}$ \\
\hline
\end{tabular}


Table 4: The most frequent combinations of deprivations among children in India 2005/06

\begin{tabular}{|l|l|c|}
\hline & & $\begin{array}{c}\text { Percent experiencing } \\
\text { 'severe' deprivation }\end{array}$ \\
\hline The most frequent case of any deprivation & Shelter & 68 \\
\hline Two most frequent combinations & Shelter/Sanitation & 52 \\
\hline Two second most frequent combinations & Shelter/Food & 22 \\
\hline The most frequent associate of food deprivation & Shelter & 22 \\
\hline The most frequent associate of education deprivation & Health & 43 \\
\hline The most frequent associate of health deprivation & Education & 43 \\
\hline
\end{tabular}

Table 5: Prevalence (\%) and Patterning of Anthropometric Failure (<-2SD) among Indian children, 0-35 months, 1998/99 and 2005/06

\begin{tabular}{|c|c|c|c|c|c|c|}
\hline \multirow[t]{2}{*}{ Prevalence } & \multicolumn{3}{|c|}{$\begin{array}{c}1998 / 1999 \\
95 \% \\
\text { Confidence } \\
\text { Interval }\end{array}$} & \multicolumn{3}{|c|}{$\begin{array}{c}2005 / 2006 \\
95 \% \\
\text { Confidence } \\
\text { Interval }\end{array}$} \\
\hline & Estimate & Lower & Upper & Estimate & Lower & Upper \\
\hline All India & 64 & 63 & 65 & 61 & 60 & 62 \\
\hline Rural & 67 & 66 & 68 & 64 & 63 & 65 \\
\hline Urban & 54 & 53 & 56 & 52 & 50 & 54 \\
\hline Male & 64 & 63 & 65 & 61 & 60 & 62 \\
\hline Female & 63 & 62 & 64 & 60 & 59 & 62 \\
\hline Scheduled Tribe (ST) & 74 & 72 & 76 & 69 & 66 & 71 \\
\hline Scheduled Caste (SC) & 70 & 68 & 71 & 67 & 65 & 69 \\
\hline Other Backward Class (OBC) & 63 & 62 & 64 & 62 & 61 & 64 \\
\hline None of above (Higher castes, etc) & 59 & 58 & 60 & 51 & 50 & 53 \\
\hline \multirow[t]{2}{*}{$\begin{array}{l}\text { Patterning of Anthropometric } \\
\text { Failure }\end{array}$} & \multicolumn{3}{|c|}{$\begin{array}{c}95 \% \\
\text { Confidence } \\
\text { Interval }\end{array}$} & \multicolumn{3}{|c|}{$\begin{array}{c}95 \% \\
\text { Confidence } \\
\text { Interval }\end{array}$} \\
\hline & Estimate & Lower & Upper & Estimate & Lower & Upper \\
\hline No Failure & 36 & 36 & 37 & 39 & 38 & 40 \\
\hline Stunted \& Underweight & 25 & 24 & 25 & 21 & 20 & 22 \\
\hline Stunted Only & 17 & 16 & 18 & 15 & 14 & 15 \\
\hline Wasted, Stunted \& Underweight & 10 & 9 & 10 & 10 & 9 & 10 \\
\hline Wasted \& Underweight & 6 & 6 & 7 & 8 & 7 & 8 \\
\hline Wasted Only & 4 & 4 & 4 & 5 & 5 & 6 \\
\hline Underweight Only & 2 & 2 & 3 & 2 & 2 & 3 \\
\hline Total & 100 & & & 100 & & \\
\hline
\end{tabular}

Source: NFHS2 and NFHS3; WHO International Reference Population. 
Table 6: The persistence of the 'Asian Enigma' for child malnutrition

\begin{tabular}{|c|c|c|c|c|}
\hline \multirow{2}{*}{ Country and Year of Survey } & \multicolumn{4}{|c|}{$\begin{array}{l}\text { Prevalence rates }(\%) \text { among children aged } 0 \text { - } \\
\qquad 35 \text { months }\end{array}$} \\
\hline & Stunting & Underweight & Wasting & CIAF \\
\hline India 2005 & 45 & 41 & 23 & 61 \\
\hline Bangladesh 2007 & 39 & 37 & 19 & 53 \\
\hline Nigeria 2008 & 40 & 23 & 16 & 52 \\
\hline Zambia 2007 & 43 & 14 & 7 & 49 \\
\hline Ethiopia 2011 & 39 & 26 & 13 & 48 \\
\hline Ghana 2008 & 24 & 15 & 12 & 35 \\
\hline Congo Brazzaville 2011 & 24 & 12 & 7 & 30 \\
\hline
\end{tabular}

Source: Demographic and Health Surveys, years as shown. WHO International Reference Population. 


\section{FIGURES}

Figure 1: Continuum of deprivation

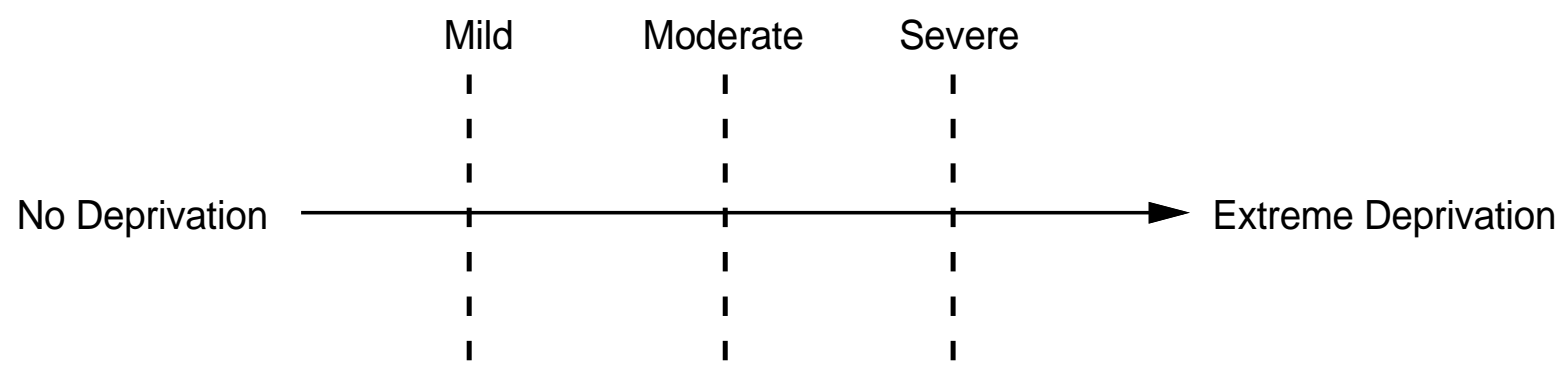

Figure 2: Absolute Child Poverty Rate by State in 2005/06

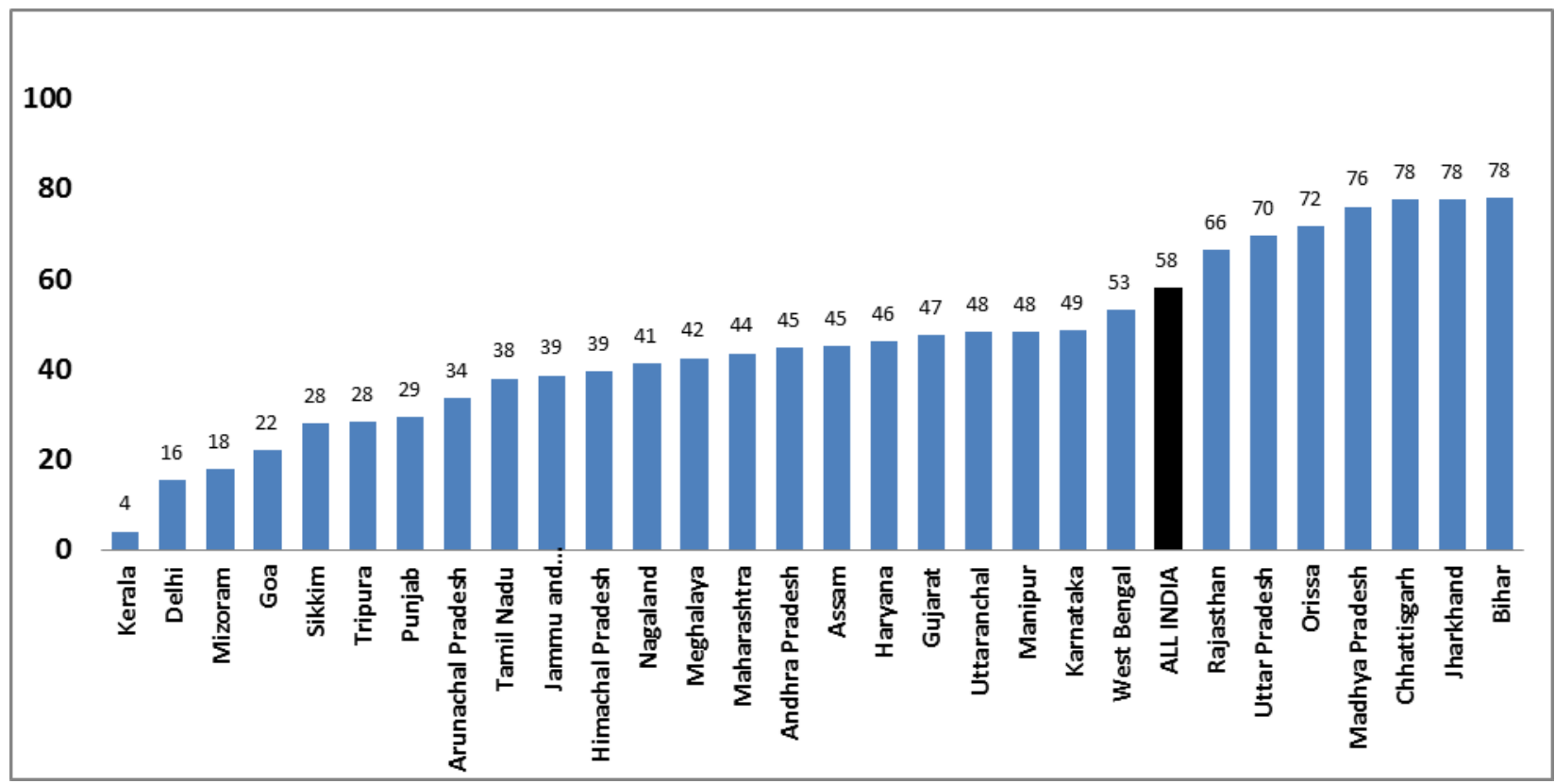


Figure 3: Absolute Child Poverty Rate by Caste Group in 2005/06

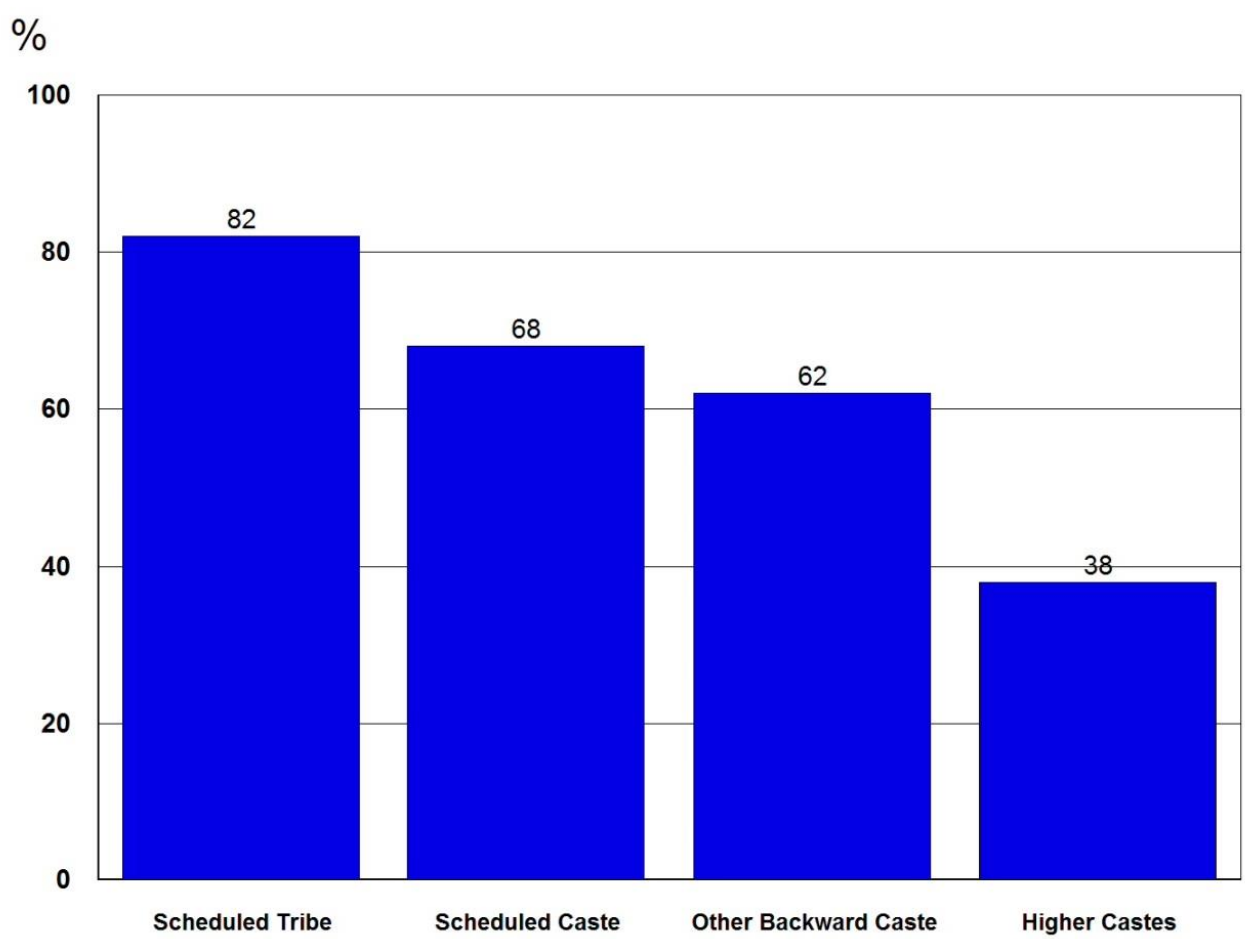

Figure 4: Absolute Child Poverty Rate by Religion in 2005/06

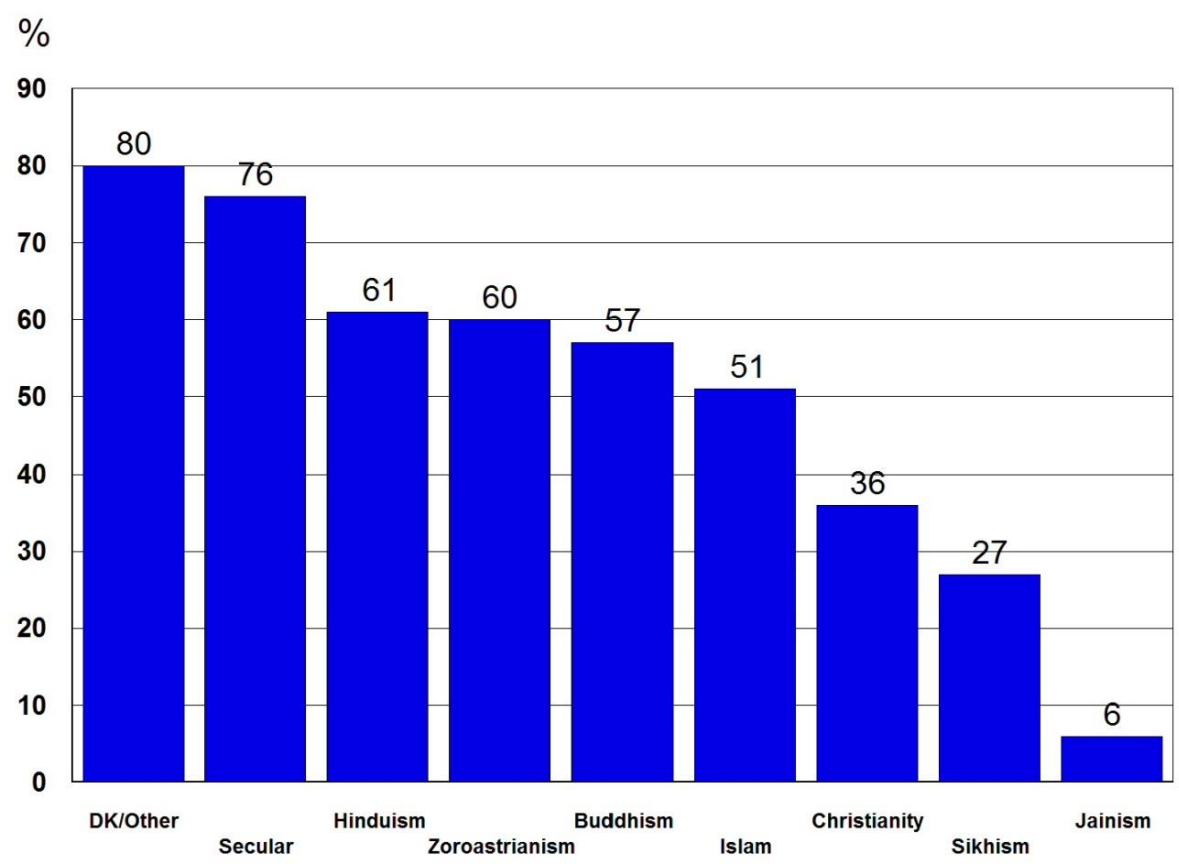


Figure 5: Absolute Child Poverty Rate by Language Spoken at Home in 2005/06

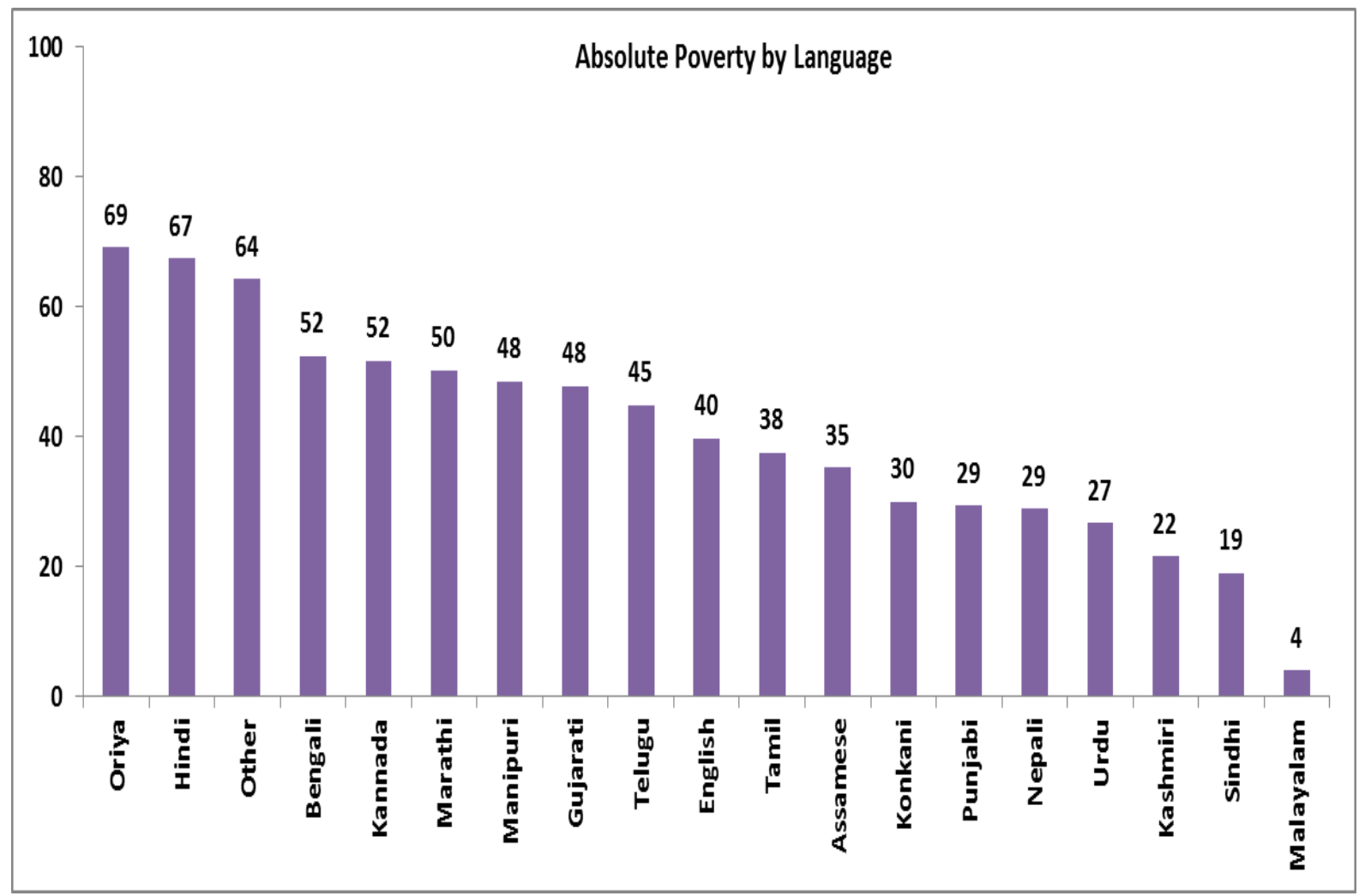




\section{Endnotes}

${ }^{\mathrm{i}}$ Global wealth is predicted to grow by $40 \%$ over the next five years, from $\$ 263$ trillion USD in 2014 to $\$ 369$
trillion USD in 2019 . It is also estimated that the richest $1 \%$ of people own $48 \%$ of global wealth (Stierli et al, 2014)

ii The term resources includes cash, food, consumer goods and service receipt - such as education, health care, water, sanitation, etc (see Townsend 1979 for a detailed discussion).

iii Martin Evans (UNICEF) per comm

${ }^{\text {iv }}$ See www.unicef.org/socialpolicy/index 45357.html

${ }^{v}$ Children's heights were not measured for a sub-set of states in the 1992/93 NFHS, making national estimates of stunting and wasting impossible.

${ }^{v i}$ India has made substantial progress in education over the past decade and significantly improved primary school enrolment rates for both boys and girls (see Table 1). Unfortunately school attendance rates have not improved as quickly and in 2014 only $71 \%$ of enrolled children in government schools were attending when they were inspected on a random day. Similarly, reading rates have also failed to improve or are declining in both government and private schools (ASER 2015).

vii India has made significant progress in improving the provision and coverage of social security, particularly with the roll out of the National Rural Employment Guarantee (NREG) since 2006. The NREG provides at least 100 days of guaranteed wage employment, however, India needs to continue to expand social security provision in order to meet the Minimum Social Protection Floor commitments it made in 2011

viii www.ilo.org/dyn/normlex/en/f?p=NORMLEXPUB:12100:0::NO::P12100_INSTRUMENT_ID:3065524

${ }^{\mathrm{ix}}$ http://www.ilo.org/secsoc/areas-of-work/policy-development-and-applied-research/social-protection-

floor/lang--en/index.htm 